\title{
ANALISIS KONSEP KUALITAS HIDUP
}

\author{
Yati Afiyanti* \\ 1. Keperawatan Maternitas Fakultas Ilmu Keperawatan Universitas Indonesia, Depok 16424, Indonesia \\ *Email: lupinavalon@hotmail.com,yatikris@ui.ac.id
}

\begin{abstract}
Abstrak
Konsep kualitas hidup mulai digunakan dalam literatur kesehatan setelah perang dunia kedua. Saat ini konsep ini menjadi penting untuk dibahas dalam mengevaluasi hasil akhir kualitas pelayanan kesehatan yang diberikan oleh para profesional kesehatan sejalan dengan tumbuhnya kesadaran bahwa kesejahteraan pasien menjadi pertimbangan yang penting dalam memilih terapi pengobatan dan untuk mempertahankan kehidupan. Kualitas hidup menjadi pertimbangan bermakna untuk masyarakat pada umumnya, dan pelayanan kesehatan pada khususnya. Namun, saat ini belum ada konsensus tentang definisi tepat dan spesifik serta alat ukur kualitas hidup. Ketiadaan konsensus ini menjadikan konsep kualitas hidup tetap meragukan. Analisis simultan terhadap konsep tersebut diharapkan dapat menghasilkan suatu konsensus definisi atribut dan alat ukur yang spesifik dan tepat dalam merumuskan konsep kualitas hidup secara operasional melalui pengembangan lebih lanjut berbagai indikator yang telah banyak digunakan dalam mengukur suatu kualitas hidup seorang individu.
\end{abstract}

Kata kunci: analisis konsep dan kualitas hidup

\section{Abstract}

The quality of life concept was first used in the health literatures after the World War II. Today this concept has become important to address in evaluating the outcome of the quality of health services provided by health professionals in line with the growing awareness that the welfare of patients becomes an important consideration when they choose medical therapy and to maintain life. Quality of life becomes meaningful to the community considerations, particularly to the health services. However, the quality of life concept currently has no consensus about the appropriate specific definition and measuring tool of quality of life. The absence of consensus leads the quality of life concepts remains ambiguous. Simultaneous analysis of the concept is expected to produce a consensus definition and measurement attribute specific and precise in formulating an operational concept of quality of life through the further development of the various indicators that have been widely used in measuring the quality of life of an individual.

Key words: concept analysis and quality of life

\section{Pendahuluan}

Konsep kualitas hidup (quality of life) telah banyak digunakan dan dilaporkan dalam berbagai literatur kesehatan (biomedik) dan keperawatan dalam sepuluh tahun terakhir Tepatnya setelah perang dunia kedua, prase kualitas hidup muncul dalam merespon pesatnya perkembangan inovasi teknologi pelayanan kesehatan dalam memperpanjang kualitas hidup individu (Haas 1999; Meeberg, 1993).

Saat ini bahasan kualitas hidup menjadi suatu pertimbangan penting untuk mengevaluasi berbagai hasil akhir efektifitas pelayanan kesehatan yang diberikan para profesional kesehatan dalam menentukan berbagai manfaat dari macam opsi/ pilihan tindakan medis yang akan diberikan kepada para pasiennya. Sebagai contoh, Anderson dan Lutgendorf (2001) mengevaluasi konsep kualitas hidup untuk menilai kualitas hidup para pasien kanker, Kleinpell (1991) menggunakan evaluasi konsep kualitas hidup para pasien di unit perawatan intensif, dan Felce (1997) menggunakan konsep ini untuk mengevaluasi kualitas hidup para pasiennya yang mengalami ketidakmampuan intektual.

Beberapa hasil analisis konsep para ahli memberikan berbagai definisi tentang kualitas hidup. Kualitas hidup didefinisikan sebagai istilah kepuasan hidup (Ferrans, 1996; Zhan, 1992), kualitas hidup didefinisikan sebagai pengalaman hidup, kepuasan hidup, dan kesejahteraan (Meeberg, 1993, Hass, 1999). Feinstein (1987) menyatakan konsep kualitas hidup sebagai suatu payung yang memayungi variasi konsep fungsional, 
status kesehatan, persepsi, kondisi kehidupan, gaya hidup, dan kebahagiaan. Namun, sampai saat ini belum terdapat suatu konsensus tentang definisi kualitas hidup yang tepat dan spesifik. Selain itu, belum juga terdapat konsensus tentang suatu alat ukur untuk menentukan/ mengukur kualitas hidup individu atau apakah kualitas hidup individu dapat atau seharusnya diukur? Belum adanya konsensus-konsensus tersebut menyebabkan kualitas hidup masih menjadi suatu konsep yang ambigu.

Makalah ini akan memberikan batasan pada pembahasan analisis konsep kualitas hidup dalam mengklarifikasi berbagai arti dari kualitas hidup, terutama dihubungkan dengan kehidupan seorang individu, mengidentifikasi berbagai penggunaan konsep kualitas hidup, mengidentifikasi karakteristik esensial dari definisi atributif konsep kualitas hidup, dan mempresentasikan berbagai konstruksi model kasus dan kasus-kasus tambahan lainnya. Penjelasan tentang antecedent, berbagai konsekuensi dan referensi empirik darikonsep kualitas hidup juga dibahas untuk melengkapi bahasan analisis konsep kualitas hidup dalam makalah ini.

\section{Klarifikasi Berbagai Arti Konsep Kualitas Hidup}

Konsep kualitas hidup pertama kali dijelaskan dalam budaya China yang memberi definisi pertama tentang kualitas hidup umumnya dikaitkan dengan nilai atau nilai tertinggi dari hidup, gambaran esensial dari suatu kehidupan, qualitas hidup sering kali dihubungkan dengan kesejahteraan. Selanjutnya WHO pada tahun 1947 mulai memperkenalkan istilah kualitas hidup dalam konteks definisi tentang sehat, yaitu suatu kondisi fisik, mental, dan kesejahteraan sosial individu terbebas dari berbagai kelemahan dan penyakit.

Sejalan dengan eksponensial waktu, konsep kualitas hidup mengalami perkembangan istilah. Berbagai indikator untuk menentukan definisi kualitas hidup dibahas dalam berbagai literatur. Frank-Stormberg (1988) mendefinisikan kualitas hidup individu secara murni dengan mengukur melalui ukuran indikator obyektif dari pendapatan, pekerjaan, edukasi, dan fungsi fisik individu.
Campbell (1976) menggunakan indikator lain, yaitu indikator sosial, dalam memberi definisi tentang kualitas hidup. Campbell menjelaskan bahwa kualitas hidup individu merupakan suatu kondisi kehidupan seseorang yang mempengaruhi kualitas hidupnya namun kondisi tersebut tidak menentukan pengalaman aktual dari seluruh kehidupannya. Di sisi lain, Pearlman dan Uhlmann (1988) menjelaskan definisi kualitas hidup dari indikator subyektif individu, yaitu persepsi seorang individu terhadap perasaan kesejahteraannya secara subyektif.

Istilah kualitas hidup juga didefinisikan menurut kamus Webster (1986) yang menyebutkan konsep kualitas hidup adalah suatu cara hidup, sesuatu yang esensial untuk menyemangati hidup, eksistensi berbagai pengalaman fisik dan mental seorang individu yang dapat mengubah eksistensi selanjutnya dari individu tersebut dikemudian hari, status sosial yang tinggi dan gambaran karakteristik tipikal dari kehidupan seorang individu.

Sejalan dengan perkembangan literatur yang secara kontinyu membahas pencarian arti konsep kualitas hidup dan berbagai indikator untuk menentukan definisi atributifkualitas hidup telah banyak diargumentasikan oleh para ahli. Namun definisi kualitas hidup masih sukar dipahami.

Berbagai variasi definisi atribut lain yang sama atau hampir sama dengan definisi kualitas hidup, seperti konsep kepuasan hidup, kesejahteraan, kebahagiaan, self-esteem, dan nilai-nilai hidup, masih perlu dibedakan dengan karakteristik definisi atributif konsep kualitas hidup itu sendiri. Sebagai konsekuensinya, konsep kualitas hidup memiliki variasi dimensi dari satu studi ke studi lainnya. Dalam beberapa studi, kualitas hidup merupakan suatu konsep yang unidimensi, sementara dalam studi lainnya, konsep kualitas hidup merupakan suatu konsep yang multidimensi.

\section{Penggunaan Konsep Kualitas Hidup}

Penggunaan konsep kualitas hidup telah banyak dibahas dalam berbagai studi yang mempelajari secara khusus penggunaan konsep kualitas hidup dalam berbagai disiplin ilmu. Pernyataan Campbell (1981), 
bahwa istilah kualitas hidup pertama kali digunakan di USA setelah perang dunia kedua untuk menggambarkan bahwa saat itu di USA terdapat kehidupan yang lebih baik daripada sekedar jaminan secara financial.

Sejalan dengan perkembangan studi-studi yang mempelajari konsep kualitas hidup, penggunaan konsep ini terus menerus digunakan untuk mengukur/ menentukan kualitas hidup individu yang dapat ditentukan dari berbagai macam indikator, yaitu indikator obyektif, subjektif, dan sosial. Melalui perkembangannya, indikator-indikator ini secara terus menerus digunakan untuk mengukur/menentukan kualitas hidup seseorang. Indicator subjektifberkaitan langsung dengan berbagai pengalaman individu menjalani kehidupan sementara indicator objektifnya dikaitkan dengan ujud kepemilikan berbagai material/ benda yang mempengaruhi berbagai pengalaman individu menjalani kehidupannya.

Sebagai contoh, dampak kepemilikan suatu benda, seperti pemilikan keadaan rumah seringkali menjadi ukuran status kesejahteraan seseorang dalam indikator obyektif. Hornquist (1982) dan Campbell, Converse, dan Rodgers (1976) menggunakan konsep hidup dalam menentukan kualitas hidup individu dari indicator subyektif dan sosial yang mencakup istilah domain/ ranah kepuasan dari berbagai pemenuhan kebutuhan fisik, psikologis, dan sosial.

Sudut lainnya dari Goodinson dan Singleton (1989) menggunakan konsep kualitas hidup melalui pencapaian pemenuhan berbagai perencanaan hidup. Di lain pihak, suatu ide komprehensif dari Moons, Budts, dan De Geest (2006) juga membahas tentang penggunaan konseptualisasi kualitas hidup sebagai suatu multi konstruksi yang membahas perilaku individu dengan berbagai kapasitas kognitif, kesejahteraan emosi, dan berbagai kemampuannya dalam menjalankan peran domestik, vokasional, dan peranperan sosialnya. Selanjutnya, penggunaan konsep kualitas hidup menjadi bagian penting dalam pelayanan kesehatan sejalan dengan makin berkembangnya realisasi bahwa kesejahteraan pasien menjadi pertimbangan yang penting ketika mereka memilih terapi pengobatan dan untuk mempertahankan kehidupannya. Kualitas hidup menjadi pertimbangan bermakna untuk masyarakat pada umumnya, dan pelayanan kesehatan pada khususnya. Konteks pengobatan pasien diasumsikan sebagai suatu cara pengobatan untuk memperpanjang dan mempertahankan kehidupannya. Saat ini, penggunaan konsep kualitas hidup juga digunakan para akademisi dalam membahas pendekatan kualitas hidup untuk mempertimbangkan kesejahteraan spiritual sebagai bagian dari konsep kualitas hidup.

\section{Definisi Atributif Karakteristik Konsep Kualitas Hidup}

Definisi atribut dari kriteria suatu konsep adalah berbagai karakteristik konsep yang seringkali muncul/ disebutkan ketika konsep tersebut didefinisikan (Walker \& Avant, 1988). Sebagai contoh, identifikasi dari beberapa atribut konsep kualitas hidup dapat membantu dalam membedakan konsep kualitas hidup dengan konsep-konsep lain yang saling berhubungan dengan konsep itu sendiri. Berdasarkan hasil pencarian dan penelusuran literatur, terdapat empat karakteristik atribut dari konsep kualitas hidup, yaitu:

1. Pernyataan rasa puas seseorang/ individu terhadap kehidupannya secara umum

2. Kapasitas mental individu untuk mengevaluasi kehidupannya sendiri sebagai suatu kepuasan atau sebaliknya

3. Suatu status fisik, mental, sosial, dan kesehatan emosi seseorang yang ditentukan oleh individu itu sendiri berdasarkan referensinya sendiri

4. Pengkajian/pengukuran objektif dari seseorang bahwa kondisi hidup seseorang adalah adekuat dan terbebas dari ancaman

\section{Konstruksi Model Kasus dan Berbagai Model Kasus Lainnya dalam Konteks Konsep Kualitas Hidup}

Penggunaan konstruksi berbagai kasus ketika melakukan analisis suatu konsep dapat memberi kemudahan dalam memahami secara tepat suatu konsep yang sedang dianalisis. Walker dan Avant (1988) menjelaskan konstruksi berbagai kasus terkait dengan suatu konsep dapat membedakan secara tepat, 
dan menjelaskan penggunaan suatu konsep dari konsep lainnya.

Berikut penjelasan menurut Walker dan Avant (1988) mengenai beberapa konstruksi kasus berupa kasus model dan kasus-kasus tambahan (kasus yang berhubungan, kasus borderline, kasus kontrari, dan kasus illegitimate).

\section{Kasus Model}

Kasus model adalah suatu konstruksi kasus yang menggambarkan kasus nyata dari kehidupan seorang individu dalam penggunaan konsep tersebut. Dalam konstruksinya, kasus tersebut memiliki semua atribut kritis dari suatu konsep dan tidak mencakup atribut lainnya di luar atribut konsep tersebut.

\section{Kasus yang Berhubungan}

Kasus yang berhubungan mengilustrasikan suatu contoh kasus yang sama dengan konsep yang sedang dianalisis, namun kasus tersebut tidak memiliki kesamaan atributif penting dari konsep yang sedang dianalisis.

\section{Kasus Borderline}

Kasus borderline merupakan contoh konstruksi kasus yang memiliki atributif penting dari suatu konsep yang dianalisis, namun tidak semua atributif penting konsep tersebut diilustrasikan dalamkonstruksi kasus tersebut.

\section{Kasus Contrary}

Kasus contrary memberikan ilustrasi yang lebih kuat dari konstruksi kasus borderline, bahkan tidak, dalam konstruksi kasus ini tidak sama sekali terkandung definisi atributif kritis dari konsep yang dianalisis.

\section{Kasus Illegitimate}

Konstruksi kasus illegitimate memberikan suatu contoh kasus, yaitu penggunaan definisi atribut yang tidak semestinya digunakan atau penggunaan definisi atribut yang salah dalam mengkonstruksikan definisi atribut ke dalamkonstruksi kasus tersebut Dengan kata lain, konstruksi kasus tersebut menggunakan definisi atributif yang salah dari konsep tersebut.

\section{Anteseden dan Berbagai Konsekuensi Konsep Kualitas Hidup}

Anteseden dan konsekuensi dari suatu konsep berfungsi memperhalus karakteristik-karakteristik penting dan dapat memberikan pencerahan terhadap definisi konsep tersebut. Anteseden adalah suatu kriteria yang harus dirumuskan sebelum suatu konsep didefinisikan. Dalam analisis konsep kualitas hidup, yang menjadi antecedent dari konsep kualitas hidup seperti yang dijelaskan oleh Walker dan Avant (1988) antara lain: untuk memiliki kualitas hidup, maka harus ada kehidupan, bukan mahluk hidup berarti tidak memiliki kualitas hidup dan keadaan sadar harus mendahului kualitas hidup (ketika seorang tidak dalam keadaan sadar, maka dirinya tidak memiliki qualitas hidup). Di sisi lain, terkait dengan berbagai konsekuensi dari analisis konsep kualitas hidup adalah segala hal yang dihasilkan/merupakan suatu konsekuensi yang berasal dari konsep tersebut. Konsep kualitas hidup memiliki berbagai konsekuensi sebagai berikut: kepuasan merupakan salah satu konsekuensi, kebahagiaan, kesejahteraan merupakan konsekuensi lainnya dan memiliki harga diri dan bangga dengan apa yang sudah dijalani dalam kehidupannya (Walker \& Avant, 1988).

\section{Referensi Empiris}

Menurut Walker dan Avant (1988), referensi empiris adalah suatu pengklasifikasian kategori/klas tentang suatu fenomena yang nyata yang keberadaannya menunjukkan kejadian dari konsep itu sendiri.Konsep kualitas hidup secara umum belum memiliki suatu standar referensi empiris yang baku, dengan kata lain konsep kualitas hidup belum dapat distandarisasi. Permasalahannya karena konsep kualitas hidup bukan merupakan suatu konsep yang absolute, tapi merupakan suatu konsep yang bersifat continuum atau berkelanjutan. Kualitas hidup tidak dapat dipertimbangkan sebagai suatu keadaan yang statis (tetap) dan setiap individu mungkin dapat menyatakan kualitas hidupnya secara berbeda dari waktu ke waktu (Carr, et al., 2001). Hal ini sejalan dengan penjelasan Peplau (1952) yang dalam teorinya menyatakan bahwa konsep kualitas hidup disamakan dengan istilah target/ konsep yang bergerak terus menerus. 
Walaupun demikian, beberapa peneliti telah mempelajari dan berusaha menyatakan berbagai argumentasi mereka dalam mengklasifikasikan tingkatan variasi dari referensi empirik konsep kualitas hidup, diantaranya Andrew dan Whitey (1974) menjelaskan referensi empirik dari konsep kualitas hidup dari tingkatan variasi indikator sosial. Andrew menjelaskan bahwa berbagai indikator subyektif konsep kualitas hidup(perasaan kepuasan, kebahagiaan, dan kesejahteraan) dapat menentukan atau mengukur secara langsung tentang tingkatan perasaan kesejahteraan seseorang. Di lain pihak, Dale (1980) menjelaskan referensi empirik konsep kualitas hidup menurut variasi indikator obyektif dan indikator subyektif.

\section{Kesimpulan}

Dasar analisis konsep kualitas hidup diawali dengan melakukan klarifikasi dari berbagai definisi konsep kualitas hidup. Secara umum, kualitas hidup adalah perasaan dan pernyataan rasa puas seorang individu akan kehidupan secara menyeluruh dan secara status mental orang lain di sekitarnya harus mengakui bahwa individu tersebut hidup dalam menjalani kehidupannya dalam kondisi yang nyaman, jauh dari ancaman, dan secara adekuat memenuhi kebutuhan dasarnya. Namun, melalui penelusuran literatur yang masih terbatas ini disimpulkan belum ada suatu consensus yang dapat memberi definisi universal/umum dari konsep kualitas hidup secara tepat dan spesifik. Setiap individu dapat memberi definisi khusus tentang kualitas hidupnya sesuai dengan referensi dan indikator (subyektif, obyektif, dan sosial) yang digunakannya (SS, INR, HR).

\section{Referensi}

Anderson, B., \& Lutgendort, S. (2001). Quality of life as an outcomes measure in gynaecologic maglignancies. Current Opinion in Obstetric \& Gynaecology, 12(1), 21-26.

Andrew, F.M., \& Whitey, S.B. (1974). Developing measures of perceived life quality: Results from several national surveys. Social Indicators Research, 1, 1-26.
Campbell, A., Converse, P., \& Rodgers, W. (1976). The quality of life (in Meeberg, G.A., 1(993). Quality of life: a concept analysis. Journal of $\mathrm{Ad}$ vanced Nursing, 18 (1), 32-38).

Campbell, A., (1981). The sense of well-being in America (Meeberg, G.A., 1(993). Quality of life: a concept analysis. Journal of Advanced Nursing, 18 (1), 32-38).

Carr, A.J., et al. (2001). Measuring quality of life: is quality of life determined by expectation or experience? British Medical Journal, 322.

Dale, B. (1980). Subjective and objective indicators in studies of regional well-being. Regional Studies, 14, 503-515.

Ferrans, C.E. (1996). Development of a conceptual model of quality of life. Scholarly Inquiry for Nursing Practice, 10 (3). 293-304.

Feinsteins, C.E. (1987). Clinical perspectives. Journal of Chronic Disease, 40 (6), 635-640.

Felce, D. (1997). Defining and applying the concept of quality of life. Journal of Intellectual Disability Research, 41, 126-135.

Frank-Stromberg, M. (1988). Instruments for clinical nursing research. Norwalk, CT: Appleton \& Lange.

Goodison, S., \& Singleton, J. (1989). Quality of life: a critical review of current concepts, measures and their clinical implications. International Journal of Nursing Studies, 26 (4), 327-41.

Haas, B.K., (1999). A multidiscipline concept analysis of quality of life. Western Journal of Nursing Research, 21 (6), 728-724.

Hornquist, J.O (1982). The concept of quality of life. Scandinavian Journal of Social Medicine, 26(2), 57-61.

Kleinpell, R.M. (1991). Quality of life of critically ill elderly patients. Chicago: University of Illinois.

Meeberg, G.A. (1993). Quality of life: A concept analysis. Journal of Advanced Nursing, 18 (1), 32-38. 
Moons, P., Budts, W., \& De Geest, S. (2006). Critique on the conceptualization of quality of life: A review and evaluation of different conceptual approaches. International Journal of Nursing Studies, 43, 891-901.

Pearlman, R.A, \& Uhlmann, R.F. (1988). Quality of life in chronic diseases: perceptions of elderly patients. Journal of Gerontology, 43 (2), M25-M30.

Peplau, H.E. (1952). The psychiatric nurse's family group. The American Journal of Nursing, 52 (12), 1475-1477.

Plummer, M., \& Molzahn, A.E. (2009). Quality of life in contemporary nursing theory: A concept analysis. Nursing Science Quarterly, 22, 142-140.
Zhan, L. (1992). Quality of life: Conceptual and measurement issues. Journal of Advanced Nursing, 17 (7), 795-800.

Walker, L.O. \& Avant K.C. (1988). Strategies for theory Construction in Nursing 2nd. (dalam Meeberg (1993). Quality of life: A concept analysis. Journal of Advanced Nursing, 18(1), 32-38).

Webster. (1986).Webster's New International Dictionary. Springfield, Mass.: Merriam-Webster Inc.

Orang-orang hebat di bidang apapun bukan baru bekerja karena mereka terinspirasi,

namun mereka menjadi terinspirasi karena mereka lebih suka bekerja.

Mereka tidak menyia-nyiakan waktu untuk menunggu inspirasi.

- Ernest Newman -

Merasa bersyukur dan menghargai seseorang atau sesuatu dalam kehidupan Anda akan menarik lebih banyak hal yang Anda hargai dan syukuri dalam hidup Anda

- Christiane Northrup -

Cara memulai adalah dengan berhenti berbicara dan mulai melakukan.

- Walt Disney -

Tidak seorang pun akan mengikutiAnda, jika Anda tidak tahu kemana harus melangkah.

- Jack Trout - 